\title{
Diversity of Immobilized Bacterial Communities and Nitrates Removal by Instantaneous Heterotrophic Denitrification Treating Nitrate-Polluted Water Using 3D-BERs-GAC: Effects of $\mathrm{pH}$ and $\mathrm{COD} / \mathrm{NO}_{3}^{-}$- N Ratio
}

\author{
Mahdi Hassan ${ }^{1}$, Guangcan Zhu ${ }^{*}, 1$, Zhonglian Yang ${ }^{1}$, Yongze $\mathrm{Lu}^{1}$ and Huang Shan ${ }^{1}$ \\ ${ }^{1}$ School of Energy and Environment, State Key Laboratory of Environmental Medicine Engineering of the \\ Ministry of Education, Southeast University, Nanjing 210096, Jiangsu, China e-mail: engrmahdi@gmail.com \\ * Correspondence: gc-zhu@seu.edu.cn
}

\begin{abstract}
In this study, a three-dimensional bioelectrochemical reactor system (3D-BERs) with granular activated carbon (GAC) epitomizes a novel treatment technology for treating nitratepolluted water. The conventional denitrification process faces many challenges, including the huge demand for organic carbon, long-term accumulation of intermediate products, and the adaptation period. Results shown that under the optimal conditions of the $\mathrm{COD} / \mathrm{NO}_{3}-\mathrm{N}$ ratio was 1.5 , the denitrification efficiency reached $98.62 \%$, when compared to $81.12 \%$ at $\mathrm{COD} / \mathrm{NO}_{3}-\mathrm{N}$ ratio of 3.5 , and the initial $\mathrm{pH}$ of $7.5 \pm 0.5, \mathrm{NO}^{-}-\mathrm{N}$ was entirely removed at $2.2 \mathrm{~h}$ without accumulation of nitrite. The high initial ratio of $\mathrm{NO}_{2}-\mathrm{N} / \mathrm{NO}_{3}-\mathrm{N}$ is mainly to accelerate the denitrification rate by accelerating the reduction of nitrite. Denitrification process followed by zero-order kinetics linear model for at different concentrations of inlet $\mathrm{NO}_{3}^{-}-\mathrm{N}$, and achieved higher denitrification rate at greater inlet $\mathrm{NO}_{3}-\mathrm{N}$ concentration. High-throughput sequencing shows that the community structure and relative abundance of bacteria changed significantly, especially at the genes and the phyla level in immobilized GAC particles. Microbial composition enhanced the removal of nitrogen at the inner surface (IS) and bottom surface (BS) of immobilized GAC carriers. Therefore, this system is expected to be a more efficient and useful supplement or a cost-effective alternative compared to the traditional low carbon to nitrogen wastewater treatment system.
\end{abstract}

Keywords: Heterotrophic denitrification; Granular activated carbon (GAC); Bacterial Community; 3D-BER system

\section{Background}

Nitrate has been considered as one of the hazardous contaminates in worldwide [1]. Nitrogencontaining compounds (e.g., $\mathrm{NO}_{3}^{-}-\mathrm{N}^{-}$or $\mathrm{NO}_{2}^{-}-\mathrm{N}$ ) released from different wastewater treatment plants (WWTPs) may seriously threaten surface and groundwater, causing eutrophication of water bodies and potentially harming human health [2]. To severe contamination of nitrogen pollution of water resources, the Chinese standards of contaminant discharge from municipal wastewater treatment plants (2002-GB18918) [3]. Therefore, due to strict environmental requirements for nutrient discharge into receiving waters, many of these other treatment technologies requisite to be developed to further eliminate the discharge of nitrate residues [4]. Moreover, the most common traditional methods for nitrate removal include adsorption [5], reverse osmosis[6], physicochemical methods [7], electrochemical methods [8], ion-exchange process[9], and biological treatment methods[10]. For physical or chemical approaches have several limitations, including high-level energy constraints, Water 2020, 12, x; doi: FOR PEER REVIEW www.mdpi.com/journal/water 
secondary pollution, and complex friable condition [3,5]. Among these various methods, biological process is usually less costly in terms of maintenance as well as operational costs compared to physical and chemical processes [10]. While the biological processes, using heterotrophic/autotrophic denitrification for nitrates can be completely reduced into nitrogen gas $\left(\mathrm{N}_{2}\right)$ without forming nitrogen residues, which shows the advantages of economic effectiveness and environmental friendliness. $[7,11]$. The biological process of nitrogen concentrations below $100 \mathrm{mg} / \mathrm{L}$ is a cost-effective and recommended method $[2,11,12]$.

There was wide range of treatment fields to be exploited in biological treatment process for treating wastewater containing nitrates $[13,14]$. Bacterial immobilization technology has been widely used in wastewater containing high amount of nitrates, organic matter and toxic chemicals $[15,16]$, which has the advantages of high biological density, strong anti-toxicity, and rapid start-up method [12]. The supporting GAC carriers play an important role in bacterial immobilization system [16]. Granular activated carbon (GAC) is an organic, non-porous polymer fixing material with a high level of mechanical strength, also fierce adaptableness to the condition, and it has proven its excellent performance, as described previously [6]. Moreover, the 3D-BERs with GAC as a fixed system to support mixed bacteria in the biological denitrification process because it can make available a gradient concentration of dissolved oxygen (DO) and sufficient active area for the growth of highdensity complex flora including bacteria that reduce nitrate and nitrite [17].

In fact, there is little literature on the applicability of GAC-based bacterial immobilization techniques in the treatment of nitrate-contaminated water. The bacterial diversity of the biofilm on the GAC carrier must be examined in the situation with a low concentration of nitrates. For the denitrification process, several intermediates are formed during the conversion process from nitrogen oxide to gaseous $\mathrm{N}_{2}$ [10]. It is known that the accumulation of a certain amount of nitratenitrogen $\left(\mathrm{NO}_{3}{ }^{-}-\mathrm{N}\right)$ under various conditions would seriously affect the removal efficiency of total nitrogen. As mentioned in previous studies [7], that have close attention to the effects of carbon sources [18], $\mathrm{pH}$, and nitrite accumulation [8]. Some researchers have worked on the mechanisms by which nitrate to nitrogen acts on anaerobic denitrification, including denitrifying enzyme activity and rich denitrification genes [19]. Traditional denitrification processes rely on the operation of four primary denitrifying enzymes, including respiratory nitrate reductase has shown;

$$
\mathrm{NO}_{3}^{-} \rightarrow \mathrm{NO}_{2}^{-} \rightarrow \mathrm{NO} \rightarrow \mathrm{N}_{2} \mathrm{O} \rightarrow \mathrm{N}_{2}
$$

As pervious showed that nitrates effects on the denitrification activity depended on existing denitrifying enzymes because heterotrophic process needs organic carbon to promote cell growth and serve as electron donors during denitrification process [10,14]. For example, Dong et al. (2017), reported that the inhibitory effect on the denitrification process is due to a related inhibition of the denitrification gene abundance that causes $\mathrm{N}_{2} \mathrm{O}$ accumulation [6]. However, few studies reported on the impact of the initial nitrate to nitrite ratio on nitrate removal and the nitrite reduction efficiency of the microbial immobilization system using GAC (MIS-GAC) immobilized microorganisms to treat wastewater. In the 3DBER-system only requires an organic carbon source to accumulates and enhance the removal of nitrogen using different $\mathrm{COD} / \mathrm{NO}_{3}-\mathrm{N}$ ratio.

Therefore, in this research work, the heterotrophic denitrification performance on the microbial diversity of the immobilized GAC biofilm carriers with non-porous polymer for treating nitratepolluted water by a novel 3D-BERs. The specific objective of the present study were to (1) extensively analyse the effect of the low inlet $\mathrm{COD} / \mathrm{NO}_{3}-\mathrm{N}$ concentration ratio on nitrogen removal, and $\mathrm{pH}$ were optimized in batch experiments; (2) to investigate the appropriate influent ratio of $\mathrm{COD} / \mathrm{NO}_{3}{ }^{-} \mathrm{N}$ range for nitrogen removal and the effect on nitrate to nitrite concentration for the nitrate reduction and nitrite accumulation; and (3) at the different concentrations of nitrates were compared to the removal of nitrogen by kinetic fitting models. Moreover, the performance of the denitrification process was studied, and the bacterial community structure on the inner and bottom surfaces of the GAC carrier was measured. Therefore, this is the first study of the removal of nitrates and enhanced the denitrification process for solving many problems in municipal wastewater treatment. 


\section{Materials and Methods}

\subsection{Reactor Configuration of the $3 D-B E R$ System}

The schematic view of the three-dimensional bioelectrochemical reactor system (3DBERs) was used in this study (Figure 1) to evaluate the diversity of immobilized bacterial communities and nitrates removal by simultaneous heterotrophic denitrification in the treatment of nitrate-polluted water. The reactor was made of plexiglass cylindrical with a diameter of $10 \mathrm{~cm}$ and a height of $20 \mathrm{~cm}$ with $0.785 \mathrm{~L}$ working volume. The reactor had total volume of $1.2 \mathrm{~L}$. The cathode consisting of eight graphite rods (height of $20 \mathrm{~cm}$ and diameter of $0.8 \mathrm{~cm}$ ) were placed around the periphery of the reactor, while the one graphite rod (height of $20 \mathrm{~cm}$ and diameter $1.5 \mathrm{~cm}$ ), as an anode was fixed in the centre of the reactor and were connected using insulated electrical copper wire by DC-power. A DC-controlled power supply: Model No: HQ3003SIII, supplied by Hansheng Puyuan Technology Beijing Co., Ltd China, ranged $(0-3 \mathrm{~A}, 0-30 \mathrm{~V})$ was used. Electrolysis of water is the decomposition of water into hydrogen $\left(\mathrm{H}_{2}\right)$ and oxygen $\left(\mathrm{O}_{2}\right)$ due to the passage of an electric current. Meanwhile, from top to bottom, space was filled with granular activated carbon (GAC) as third particle electrodes (size 1.5-3mm) used for microbial growth purchased from Younga chemical Technology (Jiangsu Co., Ltd). The GAC was the best for the growth of bacteria on cathode and anode on the inner zone and bottom zone in the reactor. The pre-treatment of GAC was washed serval times with deionized water via sulfuric acid solution $(0.01 \mathrm{M})$ and then dried for $24-30 \mathrm{~h}$, and finally at $110^{\circ} \mathrm{C}$.

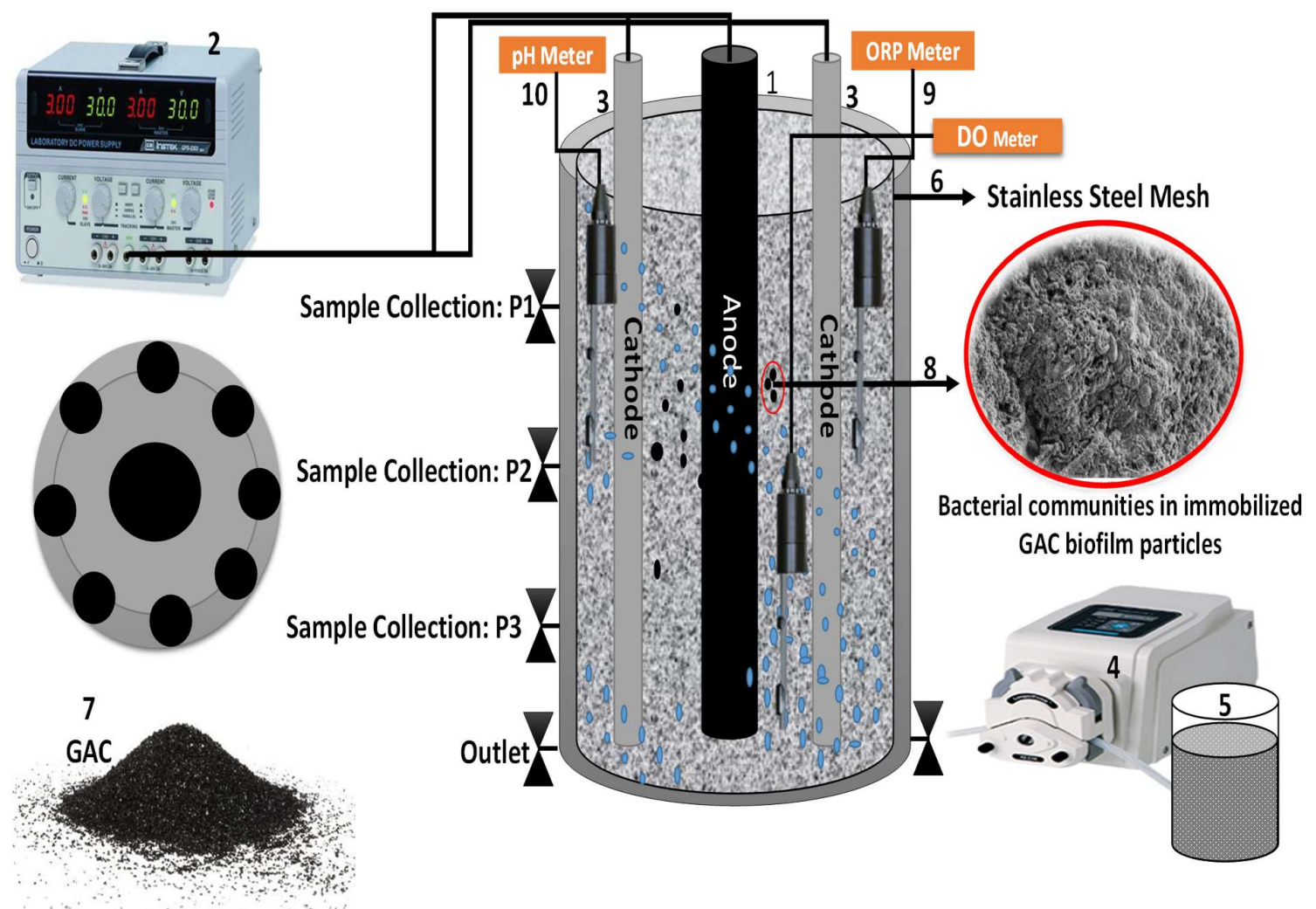

Figure 1. Schematic diagram of the 3D-BERS reactor. (1). Graphite anode rod $(\times 1)$ Size $(200 \mathrm{~mm}$ $\times 15 \mathrm{~mm})$; (2). DC regulated power supply; (3). Graphite cathode rods $(\times 8)$ size $(200 \times 8 \mathrm{~mm})$; (4). Peristaltic Pump BT300-2J; (5). Influent water tank; (6). Stainless steel mesh; (7) Granular activated carbon (GAC); (8) Bacterial communities in immobilized GAC biofilm particles (9) Portable ORP 
meter model: pH100; (10). Digital pH meter model: pH100 and Sample Collection Points (P1, P2, and P3).

\subsection{Enhancement of Denitrifying Microorganism and Synthetic Wastewater}

Denitrifying bacteria that formed the biofilm on the surface of anode/cathode and third electrode GAC in the 3D-BER system. The influent of the reactor was composed of $30 \mathrm{mgL}^{-1}\left(\mathrm{NO}_{3}^{-}-\mathrm{N}\right), 3.5$ $\mathrm{mgL}^{-1} \mathrm{~K}_{2} \mathrm{HPO}_{4}, 4.5 \mathrm{mgL}^{-1} \mathrm{NaCl}, 5.56 \mathrm{mgL}^{-1} \mathrm{KH}_{2} \mathrm{PO}_{4}, 2.75 \mathrm{mgL}^{-1} \mathrm{CaCl}_{2}$, and $0.1 \mathrm{mlL}^{-1}$ of concentrated trace elements stock solutions were prepared by dissolving; $15 \mathrm{~g} \mathrm{MgSO} .7 \mathrm{H}_{2} \mathrm{O}$, 2.2g MnSO $4 . \mathrm{H}_{2} \mathrm{O}, 2 \mathrm{~g} \mathrm{ZnSO}_{4} . \mathrm{H}_{2} \mathrm{O}, 0.24 \mathrm{~g} \mathrm{CoCl}_{2} .6 \mathrm{H}_{2} \mathrm{O}, 2 \mathrm{mg} \mathrm{NiCl} .6 \mathrm{H}_{2} \mathrm{O}, 10 \mathrm{mg} \mathrm{FeCl} 3.6 \mathrm{H}_{2} \mathrm{O}$, $0.5 \mathrm{mg} \mathrm{CuCl} 2.2 \mathrm{H}_{2} \mathrm{O}, 0.5 \mathrm{mg} \mathrm{Na} \mathrm{MoO}_{4} . \mathrm{H}_{2} \mathrm{O}$ and $15 \mathrm{~g} \mathrm{CaCl}_{2}$ into $1 \mathrm{~L}$ deionized water $[19,20]$. Synthetic wastewater used in the batch experiments with different concentrations of $\mathrm{COD} / \mathrm{NO}_{3}-\mathrm{N}$ ratio was prepared by diluting the same nutrients (including $\mathrm{NaNO}_{3}$, $\mathrm{CH}_{3} \mathrm{COONa}, \mathrm{KH}_{2} \mathrm{PO}_{4}$, and trace elements) with tap water. The $\mathrm{pH}$ of synthetic influent wastewater was typically maintained by $7.5 \pm 0.2$, and no further adjustment is required.

\subsection{Biofilm Development and System Start-up}

The system was initially started for three months with abundant anaerobic sludge (Mixed liquor suspended sludge (MLSS) of about $5.55 \mathrm{~g} / \mathrm{L}$ ) was collected as a source of inoculation from the Nanjing municipal wastewater treatment plant (WWTPs) (Table.1). Before cultivation, $1.2 \mathrm{~L}$ of anaerobic sludge water was placed into the refrigerator with nutritious solutions at $4^{\circ} \mathrm{C}$ for seven-days. During the first three days, sludge water was circulated by a magnetic pump. After 15 days, anaerobic sludge water was placed in the reactor, and $350 \mathrm{~mL}$ of tap water was added to a total volume of $785 \mathrm{~mL}$. However, electric current was not supplied to the 3D-BERs during cultivation after one week, the DC-power gradually used to $10 \mathrm{~mA}$. Before started the batch experiments, biofilm, immobilization, and acclimation were completed, and the anode-cathode electrodes, as well as the third electrode GAC, turned into dark grey at room temperature $\left(27 \pm 1.5^{\circ} \mathrm{C}\right)$. The influent was renewed two times in $24 \mathrm{~h}$ to fast growth microorganism in the reactor, and samples were collected after ten days. The $\mathrm{NO}_{2}-\mathrm{N}, \mathrm{NO}_{3}{ }^{-}-\mathrm{N}$, and denitrification efficiency were determined to evaluate the nitrate elimination in the 3D-BER system with GAC.

Table 1. The initial concentration at different $\mathrm{COD} / \mathrm{NO}_{3}{ }^{-}-\mathrm{N}$ ratio in the $3 \mathrm{D}-\mathrm{BERs}$ with immobilized GAC carriers.

\begin{tabular}{cccccccc}
\hline $\begin{array}{c}\text { Parameters } \\
\left(\mathbf{m g L}^{-1}\right)\end{array}$ & Test1 & Test 2 & Test 3 & Test 4 & Test 5 & Test 6 & Test 7 \\
\hline $\mathrm{COD}$ & 0 & 15 & 30 & 45 & 75 & 90 & 105 \\
$\mathrm{NO}_{3}^{-}-\mathrm{N}$ & 30 & 30 & 30 & 30 & 30 & 30 & 30 \\
$\mathrm{COD} / \mathrm{NO}_{3}-\mathrm{N}$ & 0 & 0.5 & 1.0 & 1.5 & 2.5 & 3.0 & 3.5 \\
\hline
\end{tabular}

\subsection{Batch Tests for the Denitrification Process}

The batch experiment was performed in the 3D-BER system to evaluate the performance of the denitrification process. All experiments were carried out in the different phases; in the $1^{\text {st }}$ phase of experiments, the $\mathrm{COD} / \mathrm{NO}_{3}{ }^{-} \mathrm{N}$ concentration ratio was ranged from " 0 to $0.5,1$ to $1.5,2.5$ to 3.0 and 3.0 to $3.5^{\prime \prime}$, and the initial $\mathrm{NO}_{3}{ }^{-}-\mathrm{N}$ concentration was $30 \pm 0.2 \mathrm{mgL}^{-1}$, and the initial $\mathrm{pH}$ level of $7.0 \pm 0.1$. Moreover, In the $2^{\text {nd }}$ phase of 
experiments, the initial $\mathrm{pH}$ was attuned to $6.0 \pm 0.2,6.5 \pm 0.5,7.0 \pm 0.1,7.5 \pm 0.4,7.8 \pm 0.6,8.2$ \pm 0.3 , and the initial $\mathrm{NO}_{3}{ }^{-}-\mathrm{N}$ concentration was $30 \pm 0.2 \mathrm{mgL}^{-1}$ with $\mathrm{COD} / \mathrm{NO}^{-}{ }^{-} \mathrm{N}$ ratio of 1.5 to 2.5.The sum of nitrate and nitrite in the average was $32 \pm 0.2 \mathrm{mgL}^{-1}$, and the initial $\mathrm{pH}$ was adjusted to $6.0 \pm 0.2,6.5 \pm 0.5,7.0 \pm 0.1,7.5 \pm 0.4,7.8 \pm 0.6,8.2 \pm 0.3$, and the initial $\mathrm{NO}_{3}{ }^{-}-\mathrm{N}$ concentration was $30 \pm 0.2 \mathrm{mgL}^{-1}$ with the ratio of $\mathrm{COD} / \mathrm{NO}_{3}^{-}-\mathrm{N}$, and in the $3^{\text {rd }}$ phase of experiments when the initial $\mathrm{COD} / \mathrm{NO}_{3}-\mathrm{N}$ was $2.5-3.5$, and the initial $\mathrm{pH}$ is $7.5 \pm 0.4$. Finally, in the $4^{\text {th }}$ phase of experiments, inlet $\mathrm{NO}_{3}{ }^{-} \mathrm{N}$ concentrations were $30 \pm 0.2,20 \pm 0.5,10 \pm 0.7$ $\mathrm{mgL}^{-1}$, when the initial ratio of $\mathrm{COD} / \mathrm{NO}_{3}{ }^{-}-\mathrm{N}$ was 0 to 3.5 , and initial $\mathrm{pH}$ was $7.0 \pm 0.1$.

In addition, the $\mathrm{NO}_{3}-\mathrm{N}$ concentrations in the influent were maintained at $30 \pm 0.2 \mathrm{mg} / \mathrm{L}$ with an initial $\mathrm{pH}$ level of $7.0 \pm 0.1$, respectively. All batch experiments were performed in triplicate and repeated at least three times. Preliminary experimental results show that immobilized microbial in 3D-BER systems with GAC would achieve relatively stable results within $8 \mathrm{~h}$. As a result, the sampling time of the batch test was controlled within $8 \mathrm{~h}$, and sampling was performed at intervals of $0.5 \mathrm{~h}, 1 \mathrm{~h}, 2 \mathrm{~h}$, and $3 \mathrm{~h}$. The performance of the 3DBER system was cultivated on the GAC particle electrode to maintain the anaerobic conditions for the growth of denitrifying bacteria. The inoculum bacteria used in this study is an efficient and complex microbial inoculum purchased from BIONETIX ${ }^{\circledR}$ International Ltd. Co. Canada. This microbial group contains 32-strains of superficial bacteria and innumerable enzymes related to bioremediation. By observing the $\mathrm{NO}_{3}{ }^{-}-\mathrm{N}$ concentration in the reactor, when nitrogen was exhausted, the residual substrate was removed, and fresh substrate was fed to the reactor to avoid endogenous metabolism of the microorganism. Then dissolved nitrogen species were measured immediately after sampling.

\subsection{DNA Extraction, PCR Amplification, and MiSeq-pyrosequencing}

The genus description of DNA extraction and PCR amplification of 16S rDNA can be found previously. However, the biofilm samples were taken from the reactor after the three months denitrification process and then dried by the freeze-drying system. The inner surface (IS) and bottom surface (BS) GAC particles electrodes biofilm were divided from the cubic feet rooftop cargo carrier (STDY-20). The biofilm samples were extracted and purified by PowerSoil-DNA Extraction Kit (MOBIO Laboratories, Carlsbad, CA92010, USA) [13].

The bacterial diversity was analyzed by Illumina-MiSeq-pyrosequencing within primers-338F (5'-ACTCCTACGGGAGGCCAGCA-3'), and $806 \quad \mathrm{R} \quad$ (5'GGACTAHVGGGTWTCTAAT-3') amplified the hypervariable zones at V3-V4 of the bacterial 16r RNA protein sequence [21] using PCR thermal cycler system (PE300, Germany) [22]. The PCR reaction was performed in the following manner: denaturation at $3 \mathrm{~min}$ for $95^{\circ} \mathrm{C}$, annealing at $55^{\circ} \mathrm{C}$ for $30 \mathrm{sec}$, extension at $72{ }^{\circ} \mathrm{C}$ for $10 \mathrm{~min}, 27$ cycle of $30 \mathrm{sec}$ at $95^{\circ} \mathrm{C}$ and elongation at $72{ }^{\circ} \mathrm{C}$ for $45 \mathrm{sec}$ [21]. However, PCR reaction was performed three-times at $20 \mu \mathrm{L}$ mixed with $4 \mu \mathrm{L}$ of $5 \times$ buffer FastPfu, $20-\mu \mathrm{L}$ of $2.5 \mathrm{mM}$ deoxyribonucleotide triphosphate (dNTP), $0.8 \mu \mathrm{L}$ of $5 \mu \mathrm{M}$ of separate primer, $0.4 \mu \mathrm{L}$ of FastPfu polymerase and $10 \mathrm{ng}$ of template-DNA. The PCR amplification products results were carried agarose-gel $2.2 \%$, and required further purified by the AxyPrep ${ }^{\mathrm{TM}}$ DNA gel-extraction Kit (Thermo Fisher Scientific, France) and measured by QuantiFlour TM-St Fluorometer Method (Mannheim, Germany) [21,23]. Then the purified amplicons of all samples were pooled in equimolar concentrations analyzed by sequenced on a high throughput Illumina-MiSeq platform with paired-end sequencing $(2 \times 250-b p)$, according to the standard protocols by Novogene Co., Ltd., Beijing, China. 


\subsection{Biofilms Samples Analysis by SEM on GAC Particles Electrodes}

The IS and BS-GAC particles electrodes surface morphology for bacteria in biofilms was examined by scanning electron microscopy (SEM). Before SEM analysis, a series of batch experiment sample processing techniques (i.e., fixing, washing, dehydration, drying, coating, etc.) were applied. Approximately $0.8 \mathrm{~g}$ of the biofilm sample was placed in a $10 \mathrm{~mL}$ centrifuge-tube and centrifuged at $6000 \mathrm{rpm}$ for $5 \mathrm{~min}$. At that time, the supernatant was removed, and then $7 \mathrm{ml}$ of $2.5 \%$ glutaraldehyde was added to mix with the sediment sample at the bottom of the centrifuge tube. Place the centrifuge tube in the refrigerator at $4^{\circ} \mathrm{C}$ for 3 to $4 \mathrm{~h}$ to fixed the sample [24]. Afterward, the tube was centrifuged for centrifugation at $6000 \mathrm{rpm}$ for $5 \mathrm{~min}$, and the supernatant was removed after centrifugation process. Add about $7 \mathrm{ml}$ of ultrapure water to the biofilm sample left at the bottom of the centrifuge tube, and centrifuge again at $6000 \mathrm{rpm}$ for $5 \mathrm{~min}$, then remove the supernatant. Such washing was performed three times by centrifugation. Next phase, the washed biofilm was dehydrated with $7 \mathrm{~mL}$ of $20 \%, 40 \%, 50 \%, 70 \%, 80 \%$, and $90 \%$ ethanol for $10 \mathrm{~min}$ each, respectively. The biofilm sample was dehydrated 3-times, with approximately $7 \mathrm{~mL}$ of $100 \%$ ethanol for 15 min each time. However, $7 \mathrm{ml}$ of a mixture of ethanol and isoamyl acetate $(100 \%$ ethanol: isoamyl acetate $=1: 1)$ were poured into the centrifuge tube for $15 \mathrm{~min}$. Although, pure isoamyl acetate was added and replaced for $20 \mathrm{~min}$. Finally, the settled samples were placed on filter paper $(10 \mathrm{~mL})$ and dried in a vacuum dryer (MechaTech system Ltd, UK) at a pre-cooling temperature of $10^{\circ} \mathrm{C}$ for $24 \mathrm{~h}$. Dry, then detonate with a $10 \mathrm{~nm}$ gold layer [22,25].

The coated samples were examined with (Hitachi S-4300 FEG-SEM), and the images were captured digitally. The SEM images are shown in Figure2 the morphology of biofilm attached to granular activated carbon (GAC) particle electrodes in the 3D-BERs. The GAC had a high specific area about $450-900 \mathrm{~m}^{2} \mathrm{~g}-1$ and a porous structure to facilitate the growth of microbial attachment as reported [17]. The biofilm samples of the inner surface (IS) were abundant compared to the bottom surface (BS) and original sludge (OS), corresponding to the thicker bacterial community. In the IS, OS zone, the microbes are less in quantity due to lacking electron donors. It was found that in the 3DBERs with immobilized GAC biofilm was imbedded in the abundance of microbial activity $[17,18]$. It was clearly observed in rod-shaped graphite anode and cathode, which was authentic common in the other denitrification system $[9,22]$. There also existed huge microbes, which may be hydrogenheterotrophic denitrifying bacteria.
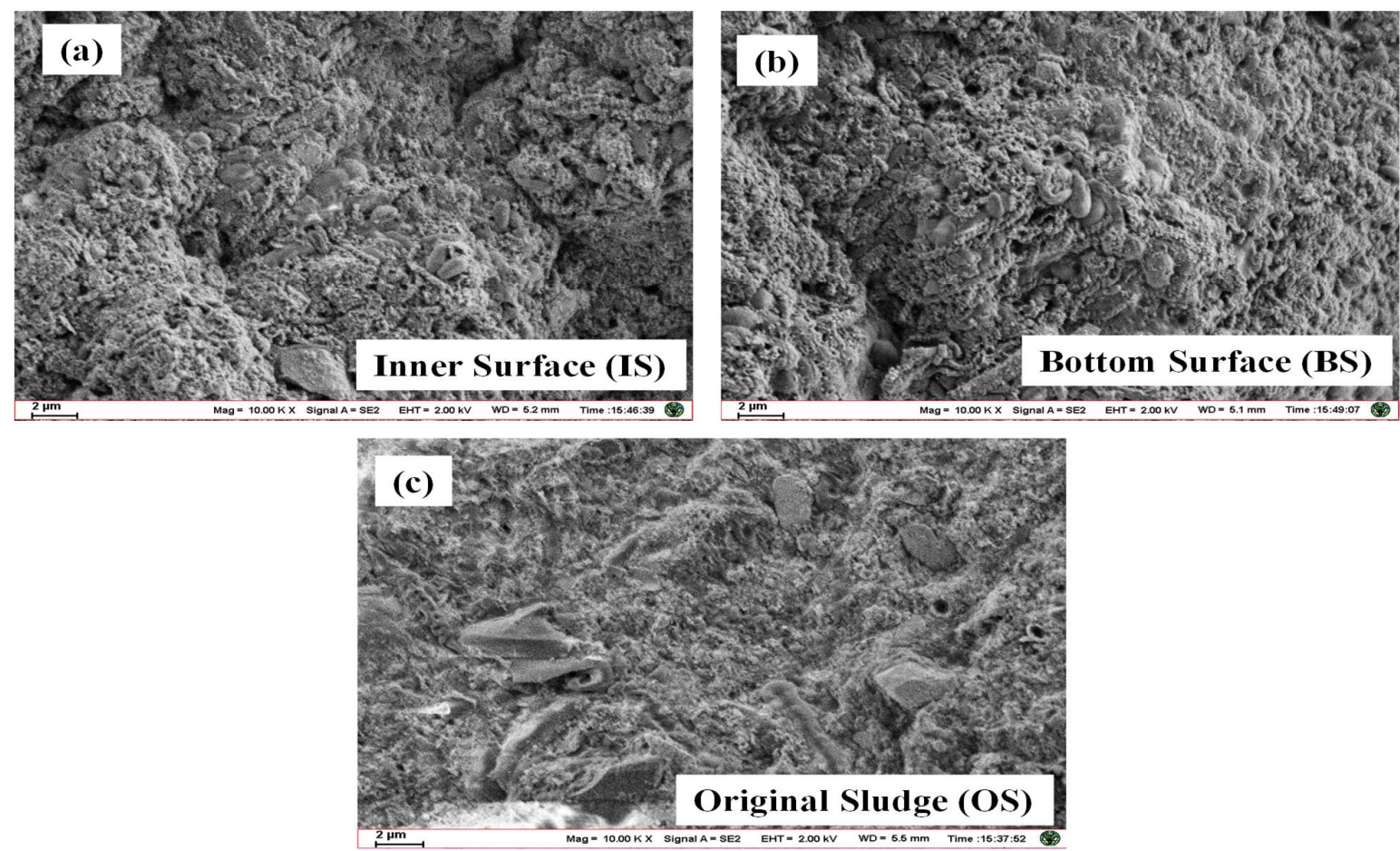
Figure 2. SEM images of (a) inner surface (IS), (b) bottom surface (BS), and (c) original sludge biofilm samples in 3D-BERs (experimental conditions: $\mathrm{COD} / \mathrm{NO}^{-}{ }^{-} \mathrm{N}=1.5-3.5, \mathrm{pH}=7.5 \pm 0.4, \mathrm{~T}=24.5 \pm 0.5^{\circ} \mathrm{C}$ ).

\subsection{Analytical Methods and Calculations}

Before measuring the indicators, all effluent samples were filtered by $0.45 \mu \mathrm{m}$ membrane filters (Millipore, Germany) before measuring the indexes, the data was obtained through average repeated sampling [26]. $\mathrm{N}-\mathrm{NO}_{3}^{-}$, was measured by an ultraviolet spectrophotometric (Shimadzu UV-1800, Japan) method at wavelength $\lambda=220-275 \times 2 \mathrm{~nm}$. Specifically, $\mathrm{N}-\mathrm{NO}_{2}^{-}$was analyzed by $\mathrm{N}$-(1-naphthyl-1, 1-ethylenediamine dihydrochloride) spectrophotometric method at $\lambda=540 \mathrm{~nm}$, respectively. The $\mathrm{pH}$ and ORP were measured by a $\mathrm{pH}$ meter model $\mathrm{pH}-100$ (Shanghai Yoke Instrument Co., Ltd., China). The chemical oxygen demand (COD) was analyzed by acidic potassium dichromate oxidation method (Digital thermos reactor, DRB200, Germany). Dissolved Oxygen (DO) value was measured by a portable DO-meter (GWQ-DO280, Xian Gavin Electronic Technology Co., Ltd China). While the monitoring of the temperature during the experiments installed an insertion thermometer in the reactor. All samples were stored at $4^{\circ} \mathrm{C}$ prior to the analysis. At least three samples were taken for each test. The removal performance of nitrate and rate were determined using the formulas $\left(C_{1}-C_{2} / C_{1} \times 100\right)$ and $\left(C_{1}-C_{2}\right) / T$, respectively. Where " $C_{1}$ " was the initial influent concentration of nitrate, and the " $\mathrm{C}_{2}$ " was the final effluent concentration of nitrate, and " $\mathrm{T}$ " is the reaction time.

\section{Results and Discussion}

\subsection{The Removal Performance of Nitrates Under different initial $p H$ and $\mathrm{COD} / \mathrm{NO}_{3}{ }^{-}-\mathrm{N}$ Ratios}

The performance of the 3D-BER system in the organic carbon-based denitrification process is the main source of bacterial respiration and better growth during heterotrophic denitrifying enzymes (Figure SI). In the case of an initial $\mathrm{NO}_{3}-\mathrm{N}$ concentration of $30 \pm 0.2 \mathrm{mgL}^{-1}$ and an initial $\mathrm{pH}$ of $7.5 \pm 0.4$, the level of $\mathrm{COD} / \mathrm{NO}^{-}-\mathrm{N}$ ratio was observed in the range of 0.5-3.5 by adding different amounts of sodium acetate as a carbon source. Under the influence of the $\mathrm{COD} / \mathrm{NO}_{3}^{-}-\mathrm{N}$ ratios, the changes of the residual $\mathrm{NO}_{3}^{-}-\mathrm{N}, \mathrm{NO}_{2}^{--} \mathrm{N}$, and the sum of the concentrations of initial $\mathrm{NO}_{3}^{--} \mathrm{N}$ and $\mathrm{NO}_{2}-\mathrm{N}$ within $8 \mathrm{~h}$ were observed in Figure 3a-b, respectively. As displayed in Figure 3a, without adding sodium acetate as a carbon source, the denitrification process is very weak. However, in this study, the presence of a definite amount of carbon source, the concentration of $\mathrm{NO}_{3}-\mathrm{N}$ has an identical tendency at different ratios of $\mathrm{COD} / \mathrm{NO}_{3}-\mathrm{N}$, and it drops rapidly within the first $1.5 \mathrm{~h}$ and then stabilizes. Since the $\mathrm{COD} / \mathrm{NO}_{3}-\mathrm{N}$ ratio increased from 0.5 to 1.0 , the residual concentration of $\mathrm{NO}_{3}-\mathrm{N}$ was not significantly reduced. In an optimal level of $\mathrm{COD} / \mathrm{NO}_{3}{ }^{-} \mathrm{N}$ ratio of 1.5 has the maximum removal of nitrate, while $\mathrm{NO}_{3}-\mathrm{N}$ completely removed in $1.2 \mathrm{~h}$. As described in Figure $3 \mathrm{~b}$, the addition of the carbon source results in decrease $\mathrm{NO}^{--} \mathrm{N}$ within $8 \mathrm{~h}$ and the suitable accumulation of nitrite. While the $\mathrm{COD} / \mathrm{NO}_{3}{ }^{-} \mathrm{N}$ ratio is between 1.5 and 2.5 , the nitrite concentration reaches $1.98 \mathrm{mgL}^{-1}$ to $1.02 \mathrm{mgL}-$ ${ }^{1}$ in $2.5 \mathrm{~h}$, and then rapidly decreasing almost $0 \mathrm{mgL}^{-1}$ within $8 \mathrm{~h}$. But, at the COD/NO $\mathrm{N}^{-} \mathrm{-N}$ ratios of 1.0 and 2.5, the nitrite concentration increased to a highest at $1.5 \mathrm{~h}$ and then gradually declined, causing a definite amount of nitrite to accumulate in $5 \mathrm{~h}$ [27]. Simultaneously, when the $\mathrm{COD} / \mathrm{NO}_{3}-\mathrm{N}$ ratio was 0.5 and 1.0, the corresponding denitrification efficiency was low. As shown in Figure 3c, the denitrification efficiency was only $49.43 \%$ and $61.12 \%$ at $4.5 \mathrm{~h}$. When the $\mathrm{COD} / \mathrm{NO}_{3}{ }^{-} \mathrm{N}$ ratio was 1.5 , the denitrification efficacy within $3 \mathrm{~h}$ reaches $98.62 \%$, as compared to $81.12 \%$ when the $\mathrm{COD} / \mathrm{NO}_{3}$ $\mathrm{N}$ ratio was 3.5 [8]. Accordingly, the increasing $\mathrm{COD} / \mathrm{NO}_{3}-\mathrm{N}$ ratio from 2.0 to 3.0 did not significantly improve the denitrification efficiency. The increase in carbon source content does not affect the removal performance of nitrates substantially, because it was provided with enough carbon source to satisfy the nutrients required for the growth of bacterial cells [19]. 

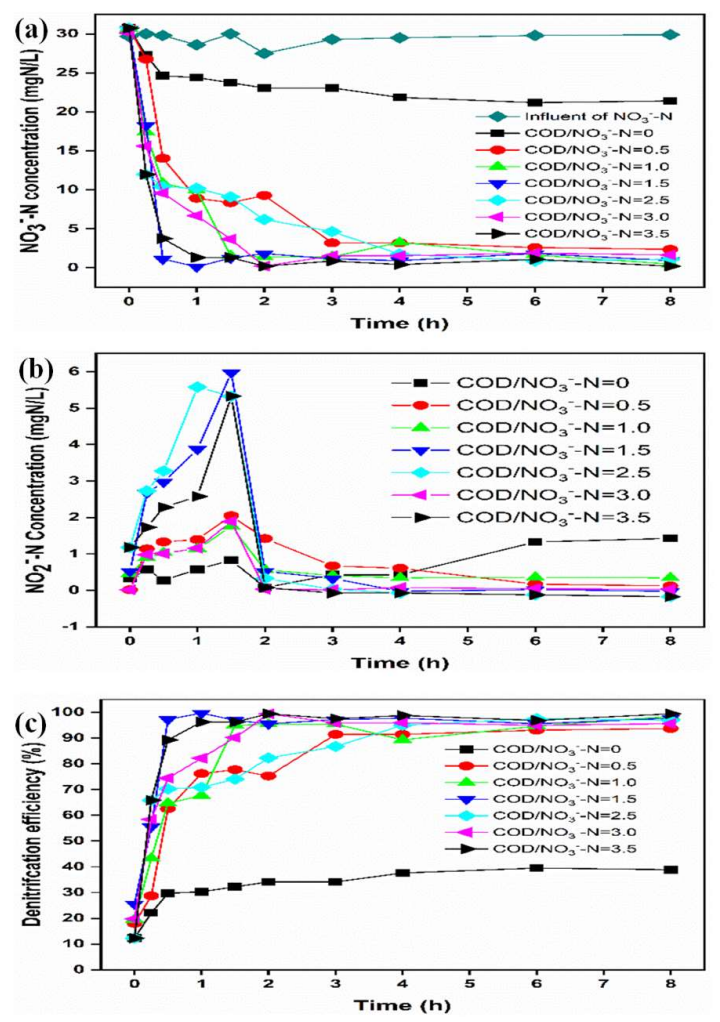
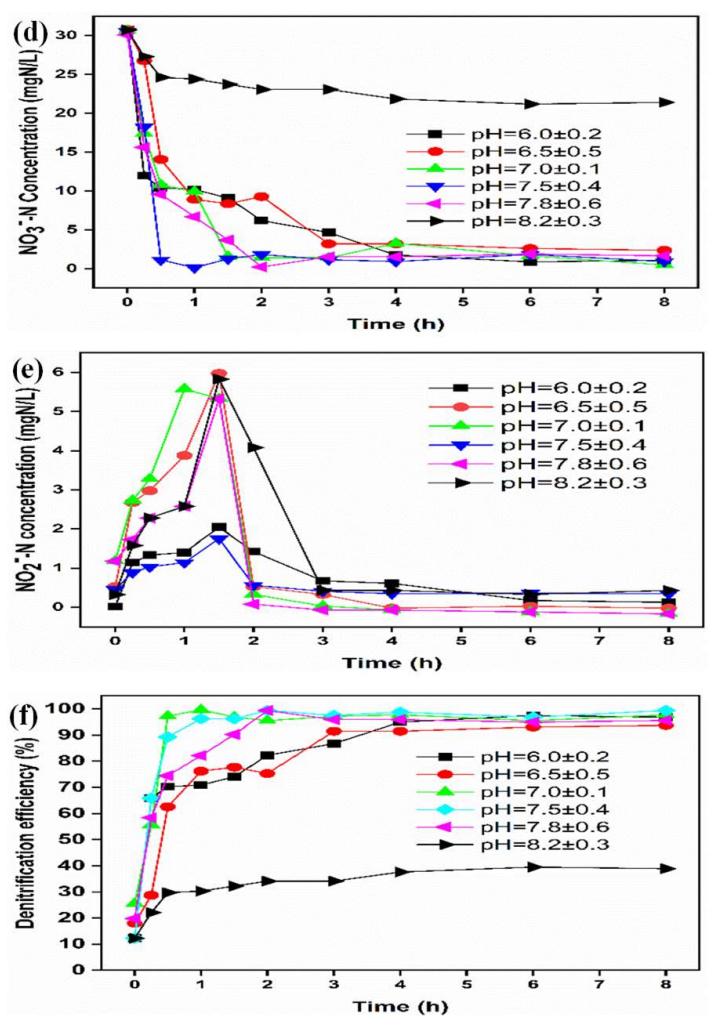

Fig. 3. The concentration and removal performance of $\mathrm{NO}_{3}-\mathrm{N}(\mathrm{a}), \mathrm{NO}_{2}-\mathrm{N}(\mathrm{b})$, and (c) denitrification efficiency during heterotrophic denitrification process, under the experimental condition: i.e., $\mathrm{pH}=7.5 \pm 0.4$, initial concentration of $\mathrm{NO}_{3}^{-}-\mathrm{N}=30 \pm 0.2 \mathrm{mgL}^{-1}$, and the ratio of $\mathrm{COD} / \mathrm{NO}^{-}-\mathrm{N}$ from 0 to 3.5 , respectively.

Heterotrophic denitrification is the process of biological nutrient removal by microorganisms using nitrate or nitrite as a nitrogen source for the development and metabolism of microbial activity, similar results were reported in the previous works [14,28]. As the carbon source used as an electron donor was significant for the complete reduction of nitrates to nitrogen gas [21,29]. The time-lapse of the concentration change of nitrate and nitrite were presented in Figure 3 . The $\mathrm{COD} / \mathrm{NO}^{-}-\mathrm{N}$ ratio had a significant effect on the reduction of nitrate compared to the reduction of nitrites, with an appropriate increase in $\mathrm{COD} / \mathrm{NO}_{3}-\mathrm{N}$ ratio, to alleviate the accumulation of nitrite [6,30]. While the substrate electrons were restricted, the competitive advantage of nitrite reduction enzymes to electrons was not as good as that of nitrate reductases. Isaka et al. [21] have been reported that the activated energy needed for a reduction in nitrite was higher than the reduction of nitrates, and the accumulation of nitrite can indicate an adequate amount of carbon sources. The removal of nitrate was an intermediate step in the denitrification process and a rate-limiting step that significantly adjust the denitrification efficiency.

Further, the reduction of nitrite was more complex for changes in the COD/ $\mathrm{NO}_{3}-\mathrm{N}$ ratio, and when the increasing $\mathrm{COD} / \mathrm{NO}_{3}-\mathrm{N}$ ratio to a certain level, providing sufficient electrons for the comprehensive denitrification, efficiently suppressed the accumulation of nitrite and the denitrification efficacy have been improved [18]. When sodium acetate is used as an electron donor, the complete denitrification ratio of nitrate to nitrogen gas is 1.5, as displayed in Equation(1) [28]

$$
8 \mathrm{NO}_{3}{ }^{-}+5 \mathrm{CH}_{3} \mathrm{COO}^{-}+8 \mathrm{H}=4 \mathrm{~N}_{2}+5 \mathrm{CO}_{2}+5 \mathrm{HCO}^{-}+9 \mathrm{H}_{2} \mathrm{O}
$$

However, in this work, an appropriate $\mathrm{COD} / \mathrm{NO}_{3}-\mathrm{N}$ ratio is required with additional cost and excess biomass in cognizance to improve denitrification efficiency, as some nitrogen will be used for 
bacterial growth. This immobilization process in 3D-BERs achieves high nitrogen removal efficiency with lower carbon source compared to previous studies [16]. The $\mathrm{pH}$ of the living environment of microorganisms may substantially affect the activity of bacterial enzymes in the reaction system. The effect of the initial $\mathrm{pH}$ on denitrification processes with an initial $\mathrm{NO}_{3}-\mathrm{N}$ concentration of $30 \pm 0.2 \mathrm{mgL}$ 1 and $\mathrm{COD} / \mathrm{NO}^{-}-\mathrm{N}$ ratio of 2.0 to 3.5 is displayed in Fig $3 \mathrm{~d}-\mathrm{f}$, respectively [18,31]. Fig $3 \mathrm{~d}$ shows that the concentration of $\mathrm{NO}_{3}-\mathrm{N}$ dropped suddenly and remained at nearby $0 \mathrm{mgL}^{-1}$ at 1.2 to $2.2 \mathrm{~h}$ at $\mathrm{pH}$ of $6.5 \pm 0.5,7.0 \pm 0.1$, and 7.5 \pm 0.4 , respectively [32]. Since the concentration of $\mathrm{NO}_{3}{ }^{-}-\mathrm{N}$ was dropped to the minimum level of $0 \mathrm{mgL}^{-1}$ after 1.2 hours, the excellent ability to reduce nitrates was shown at an initial $\mathrm{pH}$ of $7.5 \pm 0.4$.

As shown in Figure 3e, the effect of $\mathrm{pH}$ on the removal of $\mathrm{NO}_{2}-\mathrm{N}$ was significant. When the initial $\mathrm{pH}$ was $6.5 \pm 0.5,7.0 \pm 0.1$, and $8.2 \pm 0.3$, the $\mathrm{NO}_{2}-\mathrm{N}$ concentration upturn to a peak level of 3.5 to $5.8 \mathrm{mgL}^{-1}$ at $1.8 \mathrm{~h}$ and eventually dropped to $0.22,0.12$, and $0.89 \mathrm{mgL}^{-1}$ in the final, respectively. While the concentration of $\mathrm{NO}_{2}{ }^{-} \mathrm{N}$ decreased from $5.8 \mathrm{mgL}^{-1}$ in $1.2 \mathrm{~h}$, and $0 \mathrm{mgL}^{-1}$ within $3.8 \mathrm{~h}$ with an initial $\mathrm{pH}$ of $7.8 \pm 0.6$. In general, the accumulation of $\mathrm{NO}_{2}{ }^{-}-\mathrm{N}$ was a severe problem at $1-5.9 \mathrm{mg} / \mathrm{L}$, and the initial $\mathrm{pH}$ was observed at $8.2 \pm 0.3[18]$. As illustrated in Figure 3f, the applicable denitrification efficiency has occurred between the initial $\mathrm{pH}$ values of $6.5 \pm 0.5$ and $7.5 \pm 0.4$. The initial $\mathrm{pH}$ of $7.5 \pm 0.4$ seems to be the best condition for the denitrification efficiency achieved $97.7 \%$ at $3.5 \mathrm{~h}$. The diversity of microbial immobilization in the 3D-BER system, when the $\mathrm{pH}$ was $7.0 \pm 0.1-7.5 \pm$ 0.4, denitrification efficiency is high, immobilized microorganisms tend to be neutral in the alkaline environment, which was related with another research work indicating that denitrifying bacteria prefer the $\mathrm{pH}$ range of $6.2-8.2[33,34]$.

The entire heterotrophic denitrification reaction process, the GAC immobilized microorganisms, had a tremendous capability to remove nitrogen, even without the regulation of $\mathrm{pH}$. It was believed that this microbial immobilization in the 3D-BER system can accept a wide range of $\mathrm{pH}$ values and acclimatize to $\mathrm{pH}$ variations, generally because the denitrification reaction be able to mitigate the effects of $\mathrm{pH}$ on the denitrifying bacteria [18], to some extent, the $\mathrm{pH}$ of microorganisms is maintained. Nevertheless, $\mathrm{pH} 8.2 \pm 0.3$ can be described as, when the initial $\mathrm{pH}$ environment was exceedingly alkaline, the inhibition of bacterial activity due to increasing the production of alkalinity during the denitrification processes would be emphasized [5]. Also, due to the competition between nitrite and electron reductase, excessive alkalization inhibits nitrite reduction enzymes, resulting in nitrite accumulation and low nitrogen reduction efficiency $[13,23]$.

\subsection{Removal Rate of $\mathrm{NO}_{2}-\mathrm{N} / \mathrm{NO}^{-}-\mathrm{N}$ Concentration Ratios}

The effect of the initial $\mathrm{NO}_{2}-\mathrm{N} / \mathrm{NO}_{3}-\mathrm{N}$ concentration ratio on denitrification was investigated in the different $\mathrm{COD} / \mathrm{NO}_{3}-\mathrm{N}$ ratio at the range of 0 to 3.5 , when the initial $\mathrm{NO}_{3}-\mathrm{N}$ concentration was 30 $\pm 0.2 \mathrm{mgL}^{-1}$, and the initial $\mathrm{pH}$ was $7.5 \pm 0.4$. The nitrogen concentration revealed a comparable disparity tendency in the various initial concentrations of $\mathrm{NO}^{--} \mathrm{N} / \mathrm{NO}_{3}^{-}-\mathrm{N}$ ratios, which decreased dramatically throughout the period and reached $0 \mathrm{mgL}^{-1}$ at $4 \mathrm{~h}$ (Figure $4 \mathrm{a}$ ). When the COD/NO${ }^{-}-\mathrm{N}$ concentration ratio was 1.5 , the nitrogen concentration dropped below $0.5 \mathrm{mgL}^{-1}$, and the denitrification efficacy exceeded $98.5 \%$ within $3.5 \mathrm{~h}[18,23]$. However, without the inlet of nitrite, the remaining nitrogen concentration was $4.58 \mathrm{mgL}^{-1}$ at $1.5 \mathrm{~h}$. As illustrated in Figure $4 \mathrm{~b}$, the initial concentration $\mathrm{COD} / \mathrm{NO}_{3}-\mathrm{N}$ ratio increased from 0 to 1.5 , the nitrite reduction and denitrification rate both were increased, but the reduction of nitrite was inhibited. The final results showed that the high concentration of $\mathrm{NO}_{2}-\mathrm{N} / \mathrm{NO}_{3}-\mathrm{N}$ ratio accelerated the decline of nitrite, and nitrate dropped was the main feature in regulating the complete denitrification rate. 

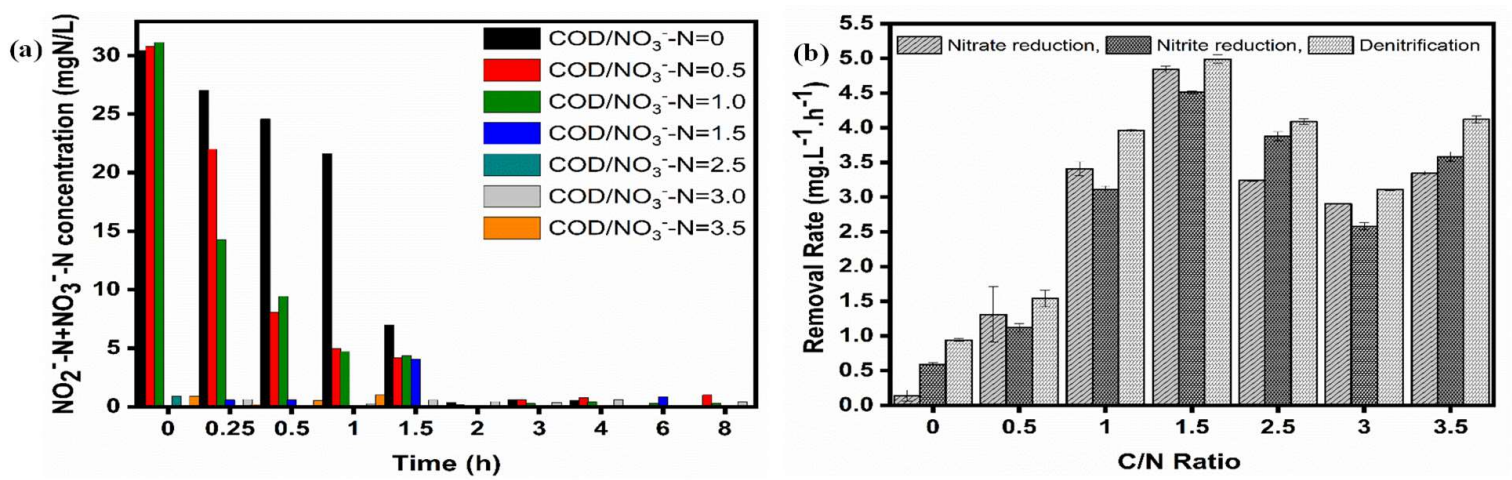

Figure 4. Concentration profile of reduction of $\mathrm{NO}_{3}^{-}-\mathrm{N}$, and $\mathrm{NO}_{2}^{-}-\mathrm{N}$ accumulation/reduction rate: under different initial concentration $\mathrm{NO}_{2}-\mathrm{N} / \mathrm{NO}_{3}-\mathrm{N}$ ratios at $2.2 \mathrm{~h}$ with optimal $\mathrm{COD} / \mathrm{NO}_{3}-\mathrm{N}$ was 1.5 (a), and denitrification removal rate $(\mathbf{b})$.

From the literature, the biomass [35], based on the concentration of the substrates and carrier structure, oxygen was not spread through a GAC-immobilization carrier, resulting in low dissolved oxygen on the inner surface of the 3D-BER system. In addition, the reductase of nitrite is more complicated to the low concentration of dissolved oxygen during the enhancement of the denitrification process, and states from top to bottom microbial activity in the process of anoxic reducing nitrite may be effectively performed in the inner or middle zone of the GAC carriers. Therefore, when the nitrogen concentration is relatively high, then the substrates dissemination limitation becomes unstable, nitrogen is removed efficiently by the middle/inner to the bottom surface supporting the GAC carrier, it can be assumed that the inner region bacteria obtain more effectively nitrogen removal [13]. Furthermore, the increasing initial concentration of $\mathrm{NO}_{2}-\mathrm{N}^{-} \mathrm{NO}_{3}-$ $-\mathrm{N}$ ratio was more positive impacts on the degradation of $\mathrm{NO}_{2}^{-}-\mathrm{N}$ than that of $\mathrm{NO}_{3}-\mathrm{N}$ [7], the purpose for which may be the reduced competition for nitrate reductase electrons shown in Figure4b.

In the absence of nitrates, the reduction rate of nitrites is higher than the rate of reduction of nitrates, as nitrate reducing enzymes can no longer compete with electrons and to reduce the transformation of an electron into nitrate and nitrite as the similar study was also reported [36].

\subsection{Kinetic Liner Fitting Models at the Different Initial Concentration of $\mathrm{NO}_{3}-\mathrm{N}$}

The performance of nitrogen removal at various initial concentrations $\mathrm{NO}_{3}-\mathrm{N}$ was studied in the range of $10 \pm 0.7$ to $30 \pm 0.2 \mathrm{mg} / \mathrm{L}$ and the concentration COD/NO$-\mathrm{N}$ ratio of 1.5 to 3.5 with the initial $\mathrm{pH}$ of $7.5 \pm 0.4$. At different initial concentrations of $\mathrm{NO}_{3}-\mathrm{N}$, nitrogen in the system can be removed at the same time, suggestive of the different initial levels of nitrate would not influence in denitrification efficacy of these microbial activities in the GAC immobilization system. Nevertheless, it can effect on the denitrifying removal rate (Figure 5a). 
(a)

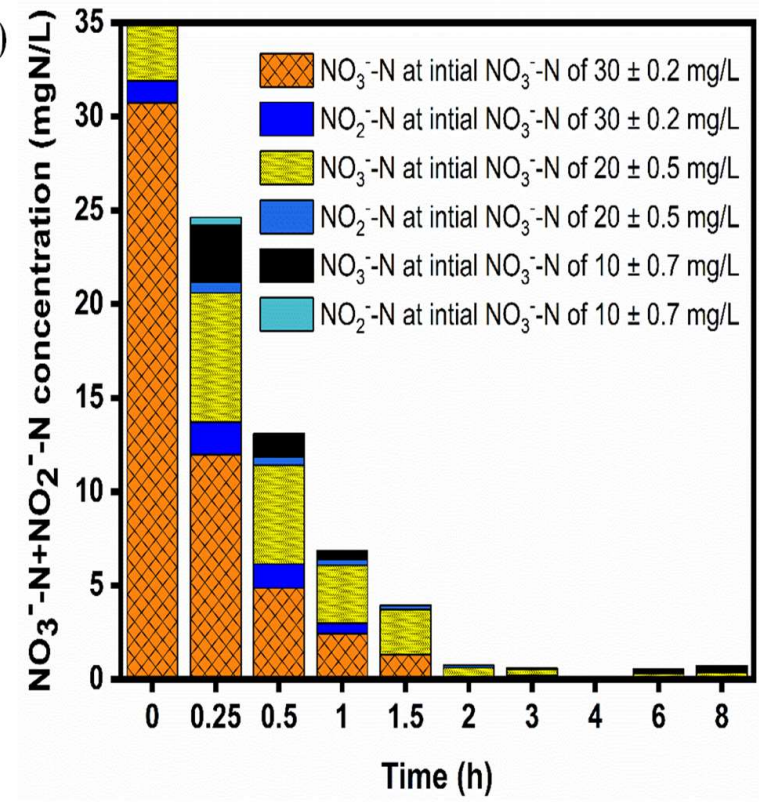

(b)

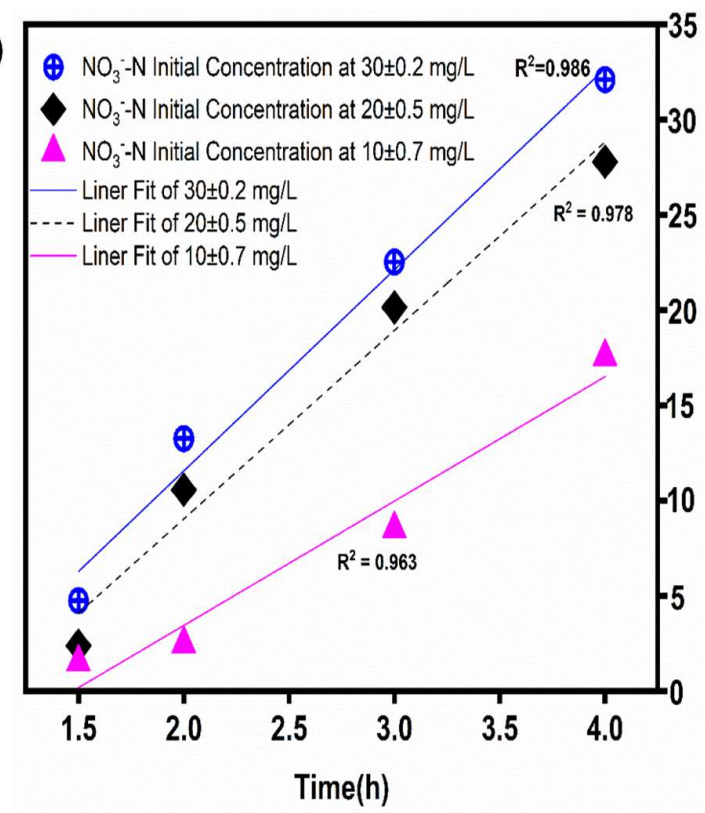

Figure 5. Operational performance of the initial concentrations of $\mathrm{NO}_{3}{ }^{-} \mathrm{N}$ were: (a) at the different initial concentration of $\mathrm{NO}_{3}-\mathrm{N}$, and (b) kinetics linear fitting models results.

In order to investigate the biological treatment of wastewater containing nitrate, the zero-order kinetic fitting model, the first-order kinetic fitting model and the second-order kinetic fitting model were used to fit the denitrification removal rate of different concentration of $\mathrm{NO}_{3}-\mathrm{N}$ at different time.

The results of the kinetics fitting linear models were presented in Table 2. The rate of correlation of the coefficient constant $\left(\mathrm{R}^{2}=0.95\right)$ of the zero-order kinetics linear fit model of different initial $\mathrm{NO}_{3}-\mathrm{N}$ concentrations was relatively more considerable than that of other fitting kinetics linear models. It was shown in Figure 5b, nicely combines the denitrification curve for different conditions with the zero-order fitting kinetics linear model, as described in Equation (3)

$$
\mathrm{C}_{\mathrm{t}}=\mathrm{C}_{\mathrm{o}}-\mathrm{K}_{\mathrm{o}} \mathrm{t}
$$

Where $\mathrm{C}_{t}$ and $\mathrm{C}_{\mathrm{o}}$ indicate the nitrate concentration $\left(\mathrm{mgL}^{-1}\right)$ at time $\mathrm{t}(\mathrm{h})$ in the influent and the effluent of the system, and -Kot is the zero-order fitting kinetics linear rate constant (mg. $\left.\mathrm{L}^{-1} \cdot \mathrm{h}^{-1}\right)$. The correlation rate of the coefficient constant was $\mathrm{R}^{2}=0.986$. The zero-order rate constant was $3.954 \mathrm{mgL}$ ${ }^{1} . \mathrm{h}^{-1}$ with an initial concentration of $\mathrm{NO}_{3}-\mathrm{N}$ was $30 \pm 0.2 \mathrm{mgL}^{-1}$, which was higher compared to the zeroorder fitting kinetics linear constant rate was $2.134 \mathrm{mgL}^{-1} \mathrm{~h}^{-1}$ and correlation rate of the coefficient constant was $\mathrm{R}^{2}=0.978$, with an initial concentration of $\mathrm{NO}_{3}^{-}-\mathrm{N}$ was $20 \pm 0.5 \mathrm{mgL}^{-1}$. While, the initial level of $\mathrm{NO}_{3}-\mathrm{N}$ was $10 \pm 0.7 \mathrm{mgL}^{-1}$, and the zero-order fitting kinetics linear constant rate was 1.986 $\mathrm{mgL}^{-1} \cdot \mathrm{h}^{-1}$, much lower through with the correlation rate of the coefficient constant was $\mathrm{R}^{2}=0.963$, presented in Table.2.

Table 2. Analysis of Kinetic fitting linear models at different initial concentrations $\mathrm{NO}_{3}-\mathrm{N}$ in the 3DBER system.

\begin{tabular}{|c|c|c|c|}
\hline $\begin{array}{c}\text { Initial } \mathrm{NO}_{3}^{-}-\mathbf{N} \\
\text { concentration } \mathrm{mgL}^{-1}\end{array}$ & $\begin{array}{c}\text { Reaction- } \\
\text { Constant rate } \\
\text { mgh }^{-1} \mathbf{L}^{-1} \\
\end{array}$ & $\begin{array}{c}\text { Correlation coefficient } \\
\text { factor }\left(\mathbf{R}^{2}\right)\end{array}$ & $\begin{array}{l}\text { Kinetics models for } \\
\mathrm{NO}_{3}^{--}-\mathrm{N} \mathrm{mgL}^{-1}\end{array}$ \\
\hline $10 \pm 0.7$ & 0.996 & 0.785 & \multirow{4}{*}{$\begin{array}{l}\text { 1st order- Kinetics } \\
\text { models }\end{array}$} \\
\hline $20 \pm 0.5$ & 0.874 & 0.675 & \\
\hline $30 \pm 0.2$ & 0.987 & 0.892 & \\
\hline $10 \pm 0.7$ & 0.982 & 0.772 & \\
\hline $20 \pm 0.5$ & 0.785 & 0.953 & \multirow{2}{*}{$\begin{array}{c}\text { 2nd order- Kinetics } \\
\text { models }\end{array}$} \\
\hline $30 \pm 0.2$ & 0.974 & 0.943 & \\
\hline
\end{tabular}




\begin{tabular}{cccc}
$10 \pm 0.7$ & 1.986 & 0.963 & \\
$20 \pm 0.5$ & 2.134 & 0.978 & Zero-order- Kinetics \\
$30 \pm 0.2$ & 3.954 & 0.986 & models \\
\hline
\end{tabular}

The results indicate that the advanced biological nitrogen removal process was performed in the 3D-BER system, and it was suitable for the description in zero-order-kinetic models that were presented, which is consistent with previous studies [37,38].

Moreover, the inlet of nitrate concentration has a great influence on the denitrification rate, and with the increase of nitrate concentration, the rate of denitrification also increases. While the denitrification increases by nearly 1.5 times when the initial level of nitrates increases by about $5 \mathrm{mgL}-$ 1 , which agreed well with the literature $[23,39]$. This could be explained by the mass transferresistance in the immobilized cell system [37]. The higher substrate concentration, and the poorer the substrate-diffusion resistance, which can to improve the substrate use and get better cell growth, and metabolism. Therefore, at the initial nitrate concentration of $30 \pm 0.2 \mathrm{mgL}^{-1}$, and a high denitrification rate of $3.954 \mathrm{mgL}^{-1} \cdot \mathrm{h}^{-1}$ was achieved in this work. Compared to the latest study combining ironreduced bacterium and iron cycles, the average rate of nitrate removal was only $0.69 \mathrm{mg} / \mathrm{L} . \mathrm{h}$ with the influent nitrate concentration of $10 \mathrm{mg} / \mathrm{L}[16,37]$. Feng Su et al.[40] reported that the advantages of heterotrophic denitrification through immobilized bacteria.

\subsection{Analysis of Microbial Community}

\subsubsection{Rarefaction Curve and Clustering Analysis}

Rarefaction analysis was employed to standardize and compare the abundance of observed taxon richness among samples and to classify the representative of collected samples. Rarefaction curve was instigated by plotting the number of sequences samples in contrast to the number of operational taxonomic units (OTUs) observed. More than 50,000 sequences were achieved for each sample. Unweighted Unifrac distance cut-off values of samples OS, IS, and BS usually are accepted as points at which variation occurs in the genus and phylum level, respectively [17]. Rarefaction curves of sample OS, IS, and BS indicate that the slopes have a tendency to flatten, which means that sequence analysis describes almost complete bacterial inhabitants and the corresponding number of OTUs (Figure 6a). The analysis of hierarchical clustering was used to show the divergence in the structure of bacterial communities in three samples, as shown in Figure 6b

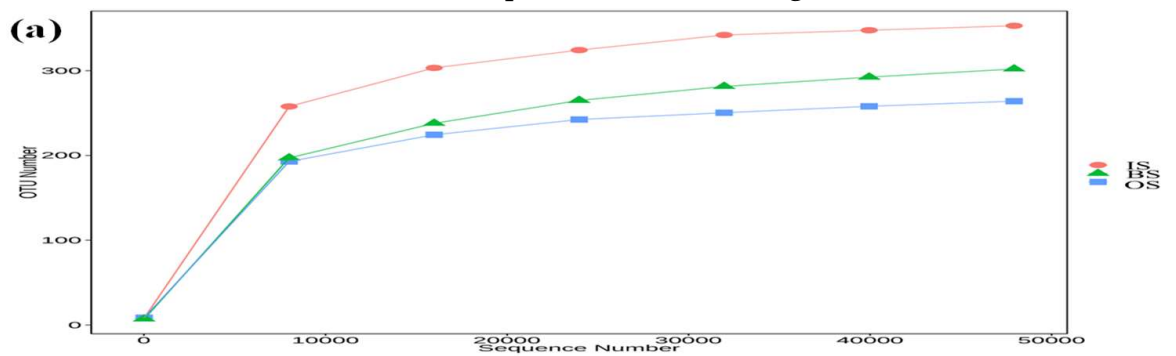

(b)

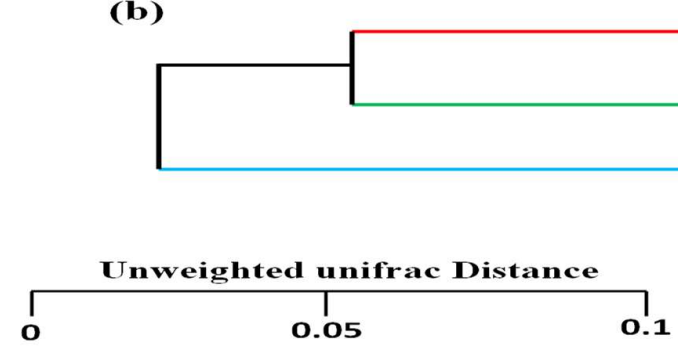

Figure 6. Microbial community at rarefaction curves (a) and hierarchical clustering analysis (b) based on Unweighted Unifrac distance of bacterial OTUs. 


\subsubsection{Diversity and Bacterial Communities Structure Analysis}

In this study, the investigation of the $16 \mathrm{~S}$ rDNA gene replicas was directed to measure the microbial community structure in the 3D-BER system. Nevertheless, the bacterial community diversity characteristic of the original sludge (OS), inner surface (IS), and bottom surface (BS) of immobilized GAC carriers were listed in Table 3. A total of 68614-82,006 effective sequences were achieved, after the quality control process of raw sequence data. The 891-1085 operational taxonomic units (OTUs) were clustered at $98.8 \%$ similarity index, and the sequencing results were shown a good replication of microbial diversity. Good coverage was relatively close to 1, and the value of Alpha $(\alpha)$ diversity of Simpson and Shannon index reduced in inner surface (IS), except for the Ace ${ }^{1}$ index, which showed an increasing tendency from OS and BS samples. It was revealed that the concentration of major functional microorganisms occurred in IS. Then, the diversity of microbial communities did not change significantly in the OS and BS samples. More than 50,000 valid reads were obtained in the sequence data processing system. Similarly, AceI and ChaoI index indicated an accumulative trend subsequently OS, IS, and BS samples showing the OTUs abundance was significantly higher in the IS area of GAC biofilm carriers, the changes consistent to the variations in the OTUs numbers. This can be attributed to the low concentration of $\mathrm{NO}_{3}-\mathrm{N}$ removal and the fact that MLSS was relatively stable during the whole operating period.

Table 3. Diversity and richness indices of the microbial community structure on the original sludge (OS), inner surface (IS), and bottom surface (BS) of immobilized GAC biofilm carriers in the 3D-BER system.

\begin{tabular}{|c|c|c|c|c|c|c|c|}
\hline Sample Name & $\begin{array}{c}\text { Effective } \\
\text { sequences } \\
\text { number }\end{array}$ & $\begin{array}{c}\text { OTUs } \\
\text { number }\end{array}$ & Ace $^{a}$ & Chao1 $^{\text {b }}$ & Simpson $^{c}$ & Shannon ${ }^{d}$ & Good's Coverage \\
\hline Original Sludge & 68,614 & 891 & 1004.18 & 985.92 & 0.949 & 6.339 & 0.997 \\
\hline Inner Surface & 82,006 & 1085 & 1229.86 & 1182.53 & 0.986 & 7.472 & 0.998 \\
\hline Bottom Surface & 73,025 & 954 & 1053.99 & 1047.44 & 0.948 & 7.252 & 0.997 \\
\hline
\end{tabular}

$a, b, d$. Community richness. A higher number represented more richness.

c. Community richness. A higher number represented less richness. e. Sampling depth.

It can be seen in Figure $7 \mathrm{a}$ and $7 \mathrm{~b}$, the relative microbial abundance at the genus and phyla levels in three samples through taxonomic analysis. At the level of the genus, the most important group of bacteria in the IS sample was Thauera, Geobacter, Desulfomicrobium, Sporomusa, and Denitratisoma, presenting for $40.06 \%, 35.45 \%, 2.81 \%, 4.59 \%$, and $2.51 \%$ of reads, respectively. Similarly, at the phylum level, the most abundant bacterial population in IS sample was Proteobacteria, Bacteroidetes, Gracilibacteria, Tenericutes, and Firmicutes were presenting for $69.01 \%, 15.88 \%, 8.48 \%, 7.16 \%$, and $2.12 \%$ of reads, the domain phylum found in three samples, respectively[41]. Therefore, phylum Proteobacteria play an important role in the denitrification process of immobilized GAC particles, meaning that the 3D-BERs exhibited excellent nitrate removal performance in the OS, IS, and BS biofilm GAC samples, whereas it was auxiliary copious in IS samples $(69.01 \%)$ compared to OS sample (49.8\%), and BS samples (60.16\%)[22]. On the GAC biofilm surface of carriers, Proteobacteria, Geobacter, Bacteroidetes, and Thauera were the dominants, accounting for $69.01 \%, 35.45 \%, 15.88 \%$, and $40.06 \%$ respectively. As shown in Figure7c, the cluster heat map generated with a three-dimensional matrix and investigated the similarities index, and dissimilarities of community between the genus level in OS, IS, and BS samples. The results indicated that the changes of bacterial community structure stuck between IS and BS sample was different. Proteobacteria, Tenericutes, Firmicutes, and Bacteroidetes were compared to the BS zone of the immobilized GAC biofilm carrier, it was abundantly present in the IS zone in 3D-BER system. 

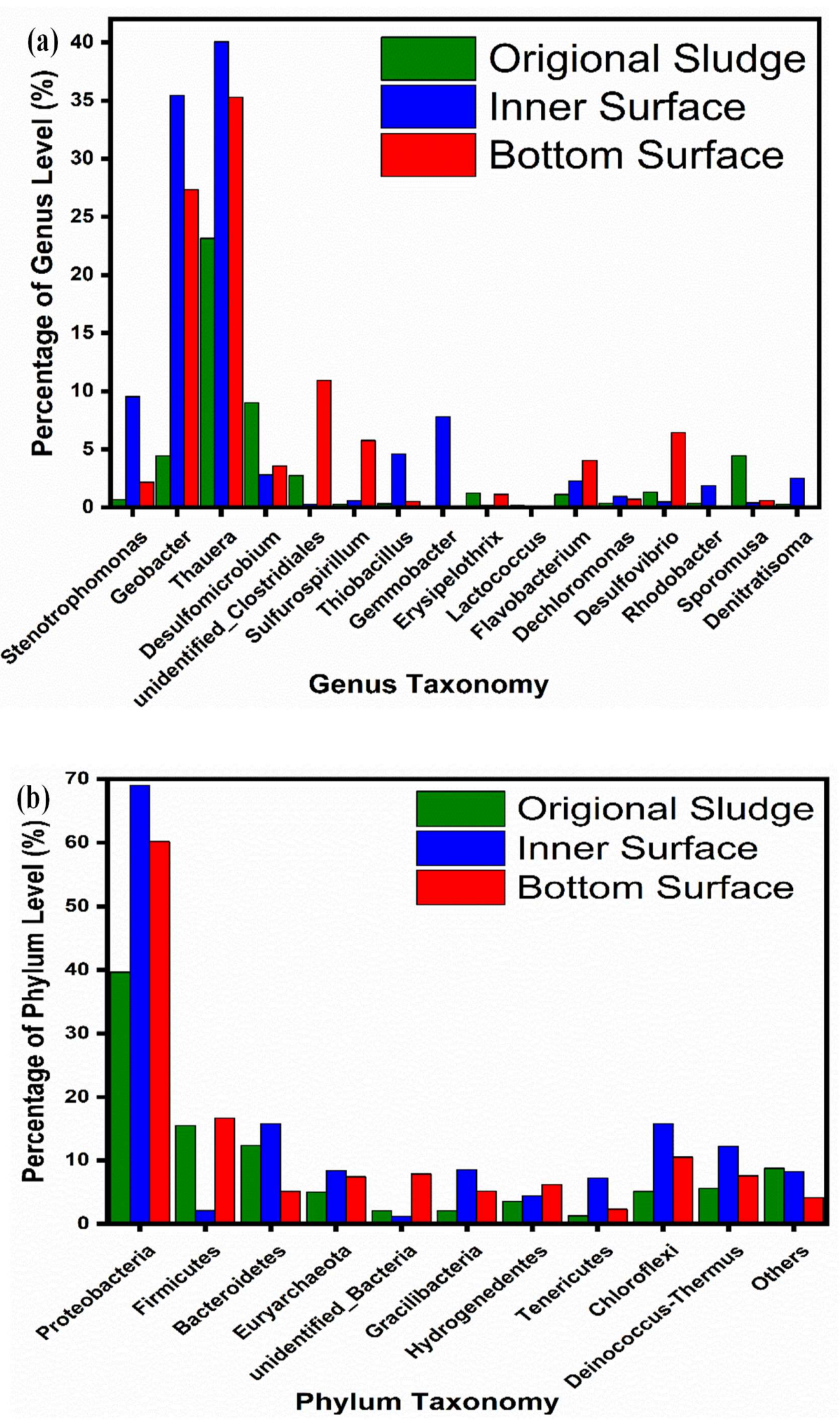


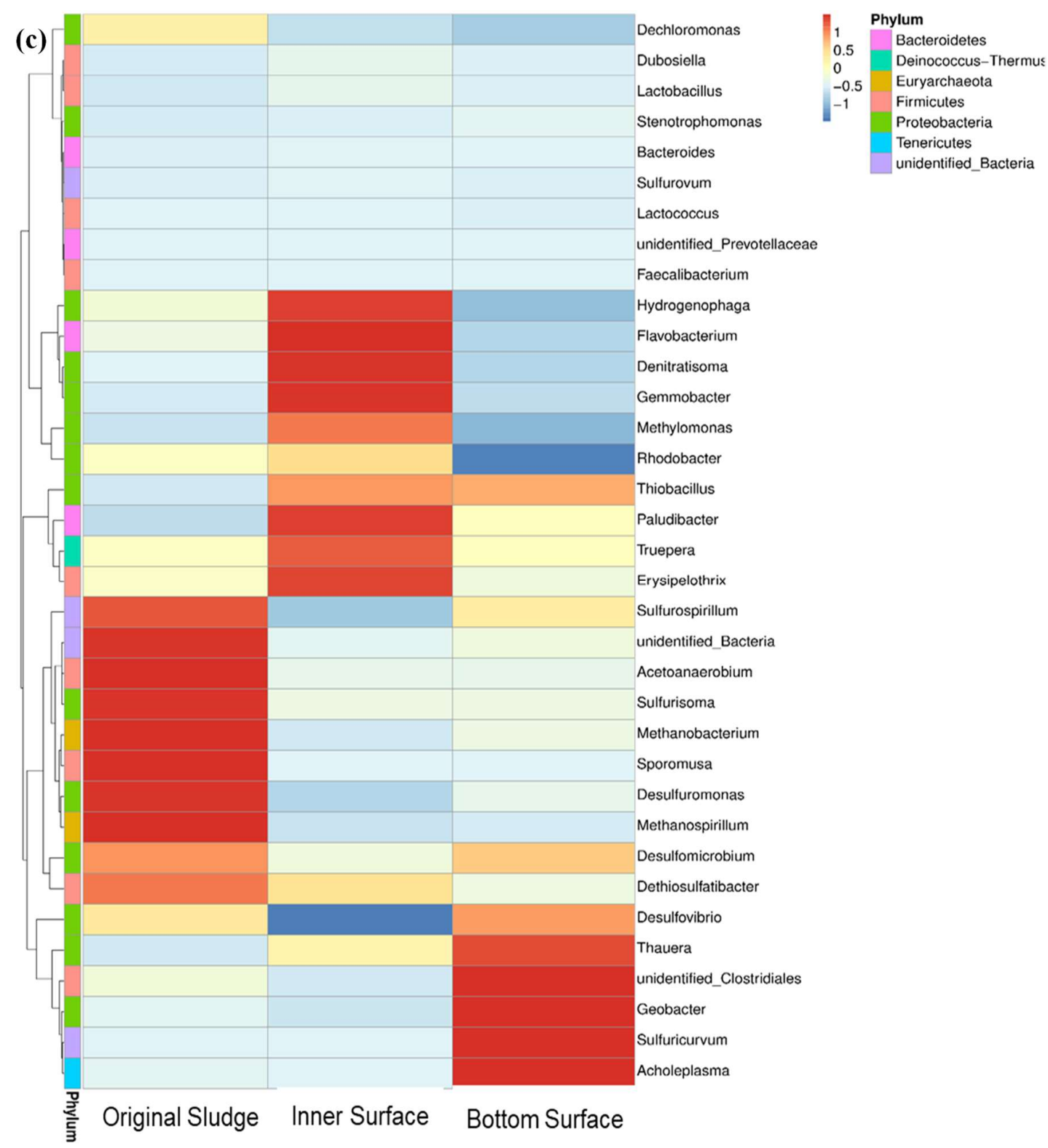

Figure 7. The microbial community compositional structure. The relative abundance of the dominant bacterial taxa in three samples at genus level (a) and phylum level (b); as well cluster heatmap at genus level in three samples (c) in the 3D-BERs.

As shown in Table 3 that the IS immobilized GAC biofilm of the carrier's possessed higher bacterial community diversity and richness. The immobilized GAC biofilm supports can provide protection for microbes, bacterial-resistance, and other species that were improved with huge inhabitants that have been sustained in the inner surface or middle region of carriers. Proteobacteria 
was the leading bacterial inhabitants placed in the IS zone of carriers (Figure7b). Recently, Proteobacteria, and Bacteroidetes, that can reduce nitrates and nitrites for the whole period of denitrification were studied in an anoxic condition [15]. Bacteroidetes, Proteobacteria, and Firmicutes found to be predominant phylum in this reactor [41] and accomplished often contributed to the denitrification process [9]. Similar results have been testified by Wang et al.[42], the phylum of the denitrification system delimited Firmicutes and Proteobacteria, which was confirmed that Proteobacteria and Firmicutes showed to have potential nitrate removal capabilities[43]. Deinococcus-Thermus from another study that Proteobacteria, Chloroflexi, and Tenericutes were the predominant microorganisms in a traditional biofilm-electrode reactor [32], wherever the Proteobacteria played significant roles in the performance of denitrification in the biofilm reactor [44]. It has been reported that Firmicutes, Proteobacteria, Deinococcus-Thermus, and Hydrogenedentes bacteria have a tendency to subsist in the anaerobic environment using organic nutrients and fatty acids source $[10,17]$. Therefore, in anaerobic environment in 3D-BER system with the GAC biofilm carriers may expedite the survival of Proteobacteria bacteria in the samples of original sludge, Inner surface and bottom surface.

The microorganisms disturbed in the mycelium making networks [32], which can improve the capability of microbes to prevent the environmental variations and auxiliary carbon source, play a vital role in municipal wastewater treatment systems[16]. According to the above mentioned experimental findings, the essential denitrifier's Pseudomonas along with diverse microbial communities contribute to the comprehensive removal of nitrate $[36,44]$. Moreover, the inner surface of the biofilm GAC was the dominant populations were Firmicutes and Proteobacteria possible to be the main reasons for the GAC immobilized bacteria to achieve denitrification [16]. However, in the denitrification process mainly occurred in the IS anoxic condition, prominent to the presence of a certain level of mass transfer-resistance. Accordingly, the removal rate of denitrification might be affected and controlled by substrate the initial concentration of nitrogen [36]. The organic carbon source in the 3D-BERs was supplemented with sodium acetate and sludge, and this would lead to a comparatively high-level proportion community of Proteobacteria (69.01\%), Bacteroidetes (15.88\%), Gracilibacteria (8.48\%), in the inner surface or middle surface of the reactor [29,35].

In conclusion, bacterial activity in the GAC immobilization in the 3D-BER system was favourable for treating nitrate-polluted water. For the complete nitrate or nitrite elimination, it would be analyzed by the transmission of substrates in the GAC biofilm-immobilized cell and the nitrate to nitrite reductase enzymes. The microbial communities' plays a significant role in the composition of the GAC immobilized carriers with different operating parameters and in the groups distributed in the above processes. In the 3D-BER system with the GAC biofilm immobilized microbial systems based on fully immobilized bacterial consortium provide space for a variety of dominant microbial community. Under the right circumstances, nitrates and intermediates can be efficiently removed according to a diverse microbial population. The best results of elimination of nitrogen and microbial community diversity in this study are very enlightening for regulating and optimizing the microbial communities the GAC immobilization cell and achieving better removal performance as well as needs for further research and application.

\section{Conclusion}

A novel three-dimensional bioelectrochemical reactor (3D-BERs) was developed to remove nitrogen from nitrate-polluted water. It was found that the optimal level of COD/ NO $3^{-}-\mathrm{N}$ ratio of 1.5 has the maximum nitrate removal, while $\mathrm{NO}_{3}-\mathrm{N}$ completely removed in $1.2 \mathrm{~h}$. With the increases of $\mathrm{COD} / \mathrm{NO}_{3}-\mathrm{N}$ ratio, a higher denitrification rate was achieved, but when the $\mathrm{COD} / \mathrm{NO}_{3}-\mathrm{N}$ ratio was lower than 1.0, the denitrification process curb was observed. When the COD/ $\mathrm{NO}_{3}-\mathrm{N}^{-}$concentration ratio was between 1.5 and 3.5, the concentration of nitrite reached 1.98 to $1.02 \mathrm{mgL}^{-1}$ in $2.5 \mathrm{~h}$, and then rapidly decreasing to $0 \mathrm{mgL}^{-1}$ within $8 \mathrm{~h}$. Notably, the denitrification removal rate could be increased with the initial nitrogen substrate. However, low initial nitrate concentration favored the nitrate removal, but the denitrification rate increased with nitrate loading $30 \pm 0.2 \mathrm{mgL}^{-1}$ and could reach as high as $3.954 \mathrm{mg} \mathrm{L}^{-1} \cdot \mathrm{h}^{-1}$ was achieved using a zero-order kinetic liner model. For the microbial 
community analyses by Illumina-Miseq high throughput pyrosequencing revealed at the genus level, Thauera, Geobacter, Desulfomicrobium, Sporomusa, and at phylum level the most abundant bacterial population in an inner surface sample was Proteobacteria, Bacteroidetes, Gracilibacteria, Tenericutes, and Firmicutes were predominantly responsible for the denitrification at $\mathrm{pH} 6.5 \pm 0.12-7.9 \pm 0.04$. Finally, in the denitrification process mostly occurred in the inner or middle surface of the GAC carriers where Thauera, Proteobacteria, and Firmicutes were the dominant microbial community. Nevertheless, the bacterial activity in the 3D-BERs was significantly inhibited when the sludge and carbon source was limited.

Declaration of Competing Interest

The authors declare no conflict of interest

\section{Authors Contributions}

M.H (PhD) wrote novel article with the help of supervisor and group teachers. Corresponding author (G.Z.PhD) design of the study work and provided suggestion in the batch experiments. Zhonglian Yang (PhD) drafted or provided critical revision of the article. Yongze $\mathrm{Lu}(\mathrm{PhD})$ participated in drafting and revised it critically for impotent intellectual facts. Huang Shan $(\mathrm{PhD})$ provided critical revision of the article and participated in drafting. All authors read and approved the final manuscript.

\section{Acknowledgement}

This scientific research work was financially supported by the National Natural Science Foundation of China under the Grant No.51578132.

\section{REFERENCES}

1. Boiocchi, R.; Gernaey, K.V.; Sin, G. Understanding N2O formation mechanisms through sensitivity analyses using a plant-wide benchmark simulation model. Chem.Eng.J. 2017, 317, 935-951.

2. Cecconet, D.; Devecseri, M.; Callegari, A.; Capodaglio, A. Effects of process operating conditions on the autotrophic denitrification of nitrate-contaminated groundwater using bioelectrochemical systems. Sci. Total.Environ. 2018, 613, 663-671.

3. Pelaz, L.; Gómez, A.; Letona, A.; Garralón, G.; Fdz-Polanco, M. Nitrogen removal in domestic wastewater. Effect of nitrate recycling and COD/N ratio. Chemosphere 2018, 212, 8-14.

4. Costa, D.D.; Gomes, A.A.; Fernandes, M.; da Costa Bortoluzzi, R.L.; Magalhães, M.d.L.B.; Skoronski, E. Using natural biomass microorganisms for drinking water denitrification. J. Environ.Manage. 2018, 217, 520-530.

5. Dhamole, P.B.; Nair, R.R.; D'Souza, S.F.; Lele, S. Denitrification of high strength nitrate waste. Bioresour.Technol. 2007, 98, 247-252. 
6. Dong, H.; Wang, W.; Song, Z.; Dong, H.; Wang, J.; Sun, S.; Zhang, Z.; Ke, M.; Zhang, Z.; Wu, W.-M. A high-efficiency denitrification bioreactor for the treatment of acrylonitrile wastewater using waterborne polyurethane immobilized activated sludge. Bioresour. Technol. 2017, 239, 472-481.

7. Kijjanapanich, P.; Yaowakun, Y. Enhancement of Nitrate-Removal Efficiency Using a Combination of Organic Substrates and Zero-Valent Iron as Electron Donors. J. Environ. Eng.2019, 145, 04019006.

8. Park, H.I.; kun Kim, D.; Choi, Y.-J.; Pak, D. Nitrate reduction using an electrode as direct electron donor in a biofilm-electrode reactor. Process.Biochem. 2005, 40, 3383-3388.

9. Zhang, Y.; Wang, L.; Han, W.; Wang, X.; Guo, Z.; Peng, F.; Yang, F.; Kong, M.; Gao, Y.; Chao, J. Nitrate removal, spatiotemporal communities of denitrifiers and the importance of their genetic potential for denitrification in novel denitrifying bioreactors. Bioresour.Technol. 2017, 241, 552-562.

10. Wang, J.; Chu, L. Biological nitrate removal from water and wastewater by solid-phase denitrification process. Biotechnol.Adv. 2016, 34, 1103-1112.

11. Öztürk, N.; Bektaş, T.E.l. Nitrate removal from aqueous solution by adsorption onto various materials. J.Hazard.Mater. 2004, 112, 155-162.

12. Ni, B.-J.; Pan, Y.; Guo, J.; Virdis, B.; Hu, S.; Chen, X.; Yuan, Z. Denitrification processes for wastewater treatment. In Metalloenzymes in Denitrification, 2016; pp. 368-418.

13. Ge, S.; Peng, Y.; Wang, S.; Lu, C.; Cao, X.; Zhu, Y. Nitrite accumulation under constant temperature in anoxic denitrification process: The effects of carbon sources and COD/NO3-N. Bioresour.Technol. 2012, 114, 137-143.

14. Firestone, M. Biological denitrification. Nitrogen in agricultural soils 1982, 22, 289-326.

15. Ma, Q.; Qu, Y.; Shen, W.; Zhang, Z.; Wang, J.; Liu, Z.; Li, D.; Li, H.; Zhou, J. Bacterial community compositions of coking wastewater treatment plants in steel industry revealed by Illumina highthroughput sequencing. Bioresour.Technol. 2015, 179, 436-443.

16. Joshi, K.; Rajan, R.; Sirnikethan, G.; Saidutta, M. Biological denitrification with immobilized Pseudomonas Syringae on granular activated carbon using three phase draft tube spouted bed reactor. Int. J.Curr.Eng.Technol.2014, 4, 3304-3309.

17. Xu, D.; Xiao, E.; Xu, P.; Lin, L.; Zhou, Q.; Xu, D.; Wu, Z. Bacterial community and nitrate removal by simultaneous heterotrophic and autotrophic denitrification in a bioelectrochemically-assisted constructed wetland. Bioresour.Technol. 2017, 245, 993-999.

18. Zhao, Y.; Zhang, B.; Feng, C.; Huang, F.; Zhang, P.; Zhang, Z.; Yang, Y.; Sugiura, N. Behavior of autotrophic denitrification and heterotrophic denitrification in an intensified biofilm-electrode reactor for nitrate-contaminated drinking water treatment. Bioresour.Technol. 2012, 107, 159-165.

19. Wang, S.-y.; Yang, X.-y.; Meng, H.-s.; Zhang, Y.-c.; Li, X.-y.; Xu, J. Enhanced denitrification by nano aFe2O3 induced self-assembled hybrid biofilm on particle electrodes of three-dimensional biofilm electrode reactors. Environ.Int. 2019, 125, 142-151.

20. Ciudad, G.; Rubilar, O.; Muñoz, P.; Ruiz, G.; Chamy, R.; Vergara, C.; Jeison, D. Partial nitrification of high ammonia concentration wastewater as a part of a shortcut biological nitrogen removal process. Process.Biochem. 2005, 40, 1715-1719.

21. Isaka, K.; Kimura, Y.; Osaka, T.; Tsuneda, S. High-rate denitrification using polyethylene glycol gel carriers entrapping heterotrophic denitrifying bacteria. Water.Res. 2012, 46, 4941-4948.

22. Chai, H.; Xiang, Y.; Chen, R.; Shao, Z.; Gu, L.; Li, L.; He, Q. Enhanced simultaneous nitrification and denitrification in treating low carbon-to-nitrogen ratio wastewater: Treatment performance and nitrogen removal pathway. Bioresour.Technol. 2019, 280, 51-58. 
23. Glass, C.; Silverstein, J. Denitrification kinetics of high nitrate concentration water: $\mathrm{pH}$ effect on inhibition and nitrite accumulation. Water.Res. 1998, 32, 831-839.

24. Cho, J.S.; Park, J.Y.; Yoo, Y.J. Novel 3-dimensional bioelectrode for mediatorless bioelectrochemical denitrification. Biotechnol.lett. 2008, 30, 1617.

25. Puig, S.; Serra, M.; Vilar-Sanz, A.; Cabré, M.; Bañeras, L.; Colprim, J.; Balaguer, M.D. Autotrophic nitrite removal in the cathode of microbial fuel cells. Bioresour.Technol. 2011, 102, 4462-4467.

26. Federation, W.E.; Association, A.P.H. Standard methods for the examination of water and wastewater. American Public Health Association (APHA): Washington, DC, USA 2005.

27. Ruiz, G.; Jeison, D.; Chamy, R. Development of denitrifying and methanogenic activities in USB reactors for the treatment of wastewater: Effect of COD/N ratio. Process.Biochem. 2006, 41, 1338-1342.

28. Rittmann, B.E.; McCarty, P.L. Environmental biotechnology: principles and applications; Tata McGraw-Hill Education: 2012.

29. Wu, Z.-y.; Liu, Y.; Wang, S.-y.; Peng, P.; Li, X.-y.; Xu, J.; Li, W.-h. A novel integrated system of threedimensional electrochemical reactors (3DERs) and three-dimensional biofilm electrode reactors (3DBERs) for coking wastewater treatment. Bioresour.Technol.2019, 284, 222-230.

30. Komorowska-Kaufman, M.; Majcherek, H.; Klaczyński, E. Factors affecting the biological nitrogen removal from wastewater. Process.Biochem. 2006, 41, 1015-1021.

31. Liu, Y.; Gan, L.; Chen, Z.; Megharaj, M.; Naidu, R. Removal of nitrate using Paracoccus sp. YF1 immobilized on bamboo carbon. J.Hazard.Mater. 2012, 229, 419-425.

32. Wang, R.-C.; Wen, X.-H.; Qian, Y. Influence of carrier concentration on the performance and microbial characteristics of a suspended carrier biofilm reactor. Process.Biochem. 2005, 40, 2992-3001.

33. Xiao, B.; Luo, M.; Wang, X.; Li, Z.; Chen, H.; Liu, J.; Guo, X. Electricity production and sludge reduction by integrating microbial fuel cells in anoxic-oxic process. Waste.Manag.2017, 69, 346-352.

34. Lin, C.; Gan, L.; Chen, Z.-L. Biodegradation of naphthalene by strain Bacillus fusiformis (BFN). J.Hazard.Mater. 2010, 182, 771-777.

35. Yang, C.; Feng, C.; Chen, N.; Deng, Y.; Hu, W.; Xue, L. Development of a novel palm fiber biofilm electrode reactor (PBER) for nitrate-contaminated wastewater treatment: performance and mechanism. Environ.Sci.Water Res.Technol. 2020.

36. Park, J.Y.; Yoo, Y.J. Biological nitrate removal in industrial wastewater treatment: which electron donor we can choose. Appl.Microbiol.Biot. 2009, 82, 415-429.

37. Vasiliadou, I.; Pavlou, S.; Vayenas, D. A kinetic study of hydrogenotrophic denitrification. Process.Biochem. 2006, 41, 1401-1408.

38. van Kessel, M.A.; Speth, D.R.; Albertsen, M.; Nielsen, P.H.; den Camp, H.J.O.; Kartal, B.; Jetten, M.S.; Lücker, S. Complete nitrification by a single microorganism. Nature 2015, 528, 555-559.

39. Cao, J.; Zhang, T.; Wu, Y.; Sun, Y.; Zhang, Y.; Huang, B.; Fu, B.; Yang, E.; Zhang, Q.; Luo, J. Correlations of nitrogen removal and core functional genera in full-scale wastewater treatment plants: Influences of different treatment processes and influent characteristics. Bioresour.Technol. 2020, 297, 122455.

40. feng Su, J.; Cheng, C.; Huang, T.; Wei, L. Performance of the dominant bacterial species and microbial community in autotrophic denitrification coupled with iron cycle in immobilized systems. Mar.Poll.Bull. 2017, 117, 88-97.

41. Wang, X.; Wen, X.; Yan, H.; Ding, K.; Zhao, F.; Hu, M. Bacterial community dynamics in a functionally stable pilot-scale wastewater treatment plant. Bioresour.Technol. 2011, 102, 2352-2357. 
42. Wang, Y.; Zhang, Z.; Qiu, L.; Guo, Y.; Wang, X.; Xiong, X.; Chen, S. Effect of temperature downshifts on biological nitrogen removal and community structure of a lab-scale aerobic denitrification process. Biochem.Eng.J. 2015, 101, 200-208.

43. Guo, F.; Liu, H. Impact of heterotrophic denitrification on BOD detection of the nitrate-containing wastewater using microbial fuel cell-based biosensors. Chem.Eng.J.2020, 125042.

44. Park, H.I.; Kim, J.S.; Kim, D.K.; Choi, Y.-J.; Pak, D. Nitrate-reducing bacterial community in a biofilmelectrode reactor. Enzyme Microb.Technol. 2006, 39, 453-458. 